\title{
LAND COVER AND LAND USE ANALYSIS OF URBAN GROWTH IN ROMANIA
}

\author{
Alexandru-Ionuţ Petrișor \\ "Ion Mincu" University of Architecture and Urbanism, Bucharest, Romania
}

\begin{abstract}
While cities appeared and disappeared during the history, and different disciplines, such as ecology and geography attempted to model the process from a systemic perspective, the growth of modern cities, particularly under the form of urban sprawl, is an important phenomenon due to its environmental and socioeconomic impacts. CORINE data allow for analyzing the growth of cities based on the changes in land cover and use. This study aimed to assess the magnitude of long-term urban growth in Romania, chosen as an example of a transition country, hypothesizing that the phenomenon is visible at the national scale. The results locate urban growth in area where the real estate boom is prominent, but its extent is masked by the small share of urban areas from the total territory. If growth is analyzed in relationship to the urban area, its magnitude becomes visible, supporting the underlying hypothesis.
\end{abstract}

Key words: Urban growth, CORINE, GIS, Kriging, Transition.

Article Info: Manuscript Received: January 3, 2012, Revised: April 29, 2012; Accepted: May 15, 2012; Online: May 29,2012

\section{Introduction}

Even if covering a small portion of land compared to natural and agricultural areas, cities concentrate most of the human population. Their growth has been a topic of interest for many sciences. "Cities are born, change and sometimes disappear based on the creation or closure of commercial routes, development or decline of industrial manufacturing processes, discovery or exhaustion of mining resources, or development of services and tourism" (Lacaze, 1990). After the emergence of the systemic conception, several theories were proposed to account for the growth of cities. Ecologists replaced the model based on succession stages (Botnariuc \& Vădineanu, 1982) with another one relying on adaptive cycles (Holling, 2004). Both models were applied to all ecological systems, regardless of being natural or artificial. Nevertheless, geographers have recently proposed an evolutionary model applicable to cities, describing the process using a spiral, to account for the fact that a state resulted from returning to a previous typology is qualitatively

\footnotetext{
* Correspondence address:

Address: "Ion Mincu" University of Architecture and Urbanism, str. Academiei 18-20, sector 1, 010014, Bucharest, Romania.

Telephone: +4021-307-7133

Email: a.i.petrisor@gmail.com
}

different from its predecessor (Ianoș et al., 2011).

A particular perspective in describing the growth of cities is the spatial one. Different patterns can be found across time and space due to physical, geographic, cultural, legislative, administrative, social, economic or environmental constraints (Mitrea, 2008; Petrişor, 2008a); essentially, they can be classified as compact (e.g., concentric, grid, or linear) and diffuse (e.g., patches, tentacles, strips, federative). The growth of cities determines, accounting for the limitation of space, the transformation of adjacent areas, natural or agricultural, into urban regions (Ianoș et al., 2011; Petrişor and Sârbu, 2010).

In this context, it is important to look at the peripheral zones. Similar to the natural systems, the urban fringe can be assimilated to the ecotone area separating two ecosystems (Stan, 2009; Petrișor, 2011). However, when analyzing its function, a major difference can easily be detected: while in natural systems, the ecotone provides for the productivity of the two systems, since it is inhabited by species involved in their food webs (Botnariuc \& Vădineanu, 1982), this is not true for the urban periphery in any respect. Moreover, the later is often associated, from a social viewpoint, with exclusion or ecological racism (Petrișor, 2008a), defined as 'discrimination in environmental policy making' and important for its 
consequences on land use, among others (Bullard, 2004). Due to the prominent belonging of urban peripheries to the city, they are spatially noticeable, unlike the natural ecotone, which is often hiding the boundaries of the two systems.

Due to the good visibility of its limits, the growth of a city can easily be analyzed by looking at the changes of land cover and use. The analysis of such phenomena is important in regard to urban growth. The negative impacts and magnitude of European urban growth taking the form of sprawl has been analyzed in a European Environment Agency report (EEA, 2006). Out of the most important consequences, it is noteworthy mentioning environmental impacts on natural resources and energy, protected and rural areas, life quality and health, and socioeconomic impacts including segregation, polarization, increased costs and lower economic efficiency, and decreased quality of urban transportation. In its turn, the lower quality of transport services has been found among the leading causes of urban sprawl (Salas-Olmedo and Nogués, 2010).

One of the methods for analyzing urban growth relies on CORINE Land Cover (CLC) data, classified on three levels. Jensen (200o) defines land cover (LC) as "biophysical materials found on the land" and land use (LU) as "how the land is being used by human beings". The CORINE Program of the European Union uses similar definitions, distinguishing between a functional and a sequential approach for defining land use; the first is similar to Jensen's definition, and the second describes the particular operations performed by humans who use the land (European Commission, 2001). In addition to these definitions, Petrişor et al. (2010) make a difference between natural and artificial systems, considering that LU reflects a detailed typology of natural systems and the utilization of the artificial ones by human communities. In addition, the authors showed that LC is described by the first level of CLC classification (CLC1) and $L U$ by the next levels ( $C_{1} C_{2}$ and 3 ), depending on the extent of details.

The transition of the Romanian economy to and open market system after a long period of centralization makes the country a good candidate for looking at long term environmental changes, particularly at phenomena related to the growth of cities, from a land cover and use viewpoint.

This study proposes a GIS-based methodology to look at the growth of Romanian cities by the expansion of their limits, as reflected by CORINE data, testing the hypothesis according to which such a methodology is able to assess the national extent of their growth, generalizing at larger scale phenomena previously analyzed locally. Moreover, the analysis aims to underline the socio-economic consequences in addition to the environmental ones.

\section{Data and Methods}

CORINE data is especially useful to assess changes of large areas over long periods (Petrişor, 2008b). One of the approaches developed based on CORINE data, proposed by Petrişor et al. (2010), distinguished three phenomena, based on the type of change: urbanization, if an area other than artificial (according to CORINE classification) changes its LC to artificial; urban restructuring, if LC remains artificial, but LU changes; and deurbanization, if LC changes from artificial to another type. The approach developed in this study is merely geographic, provided that data was analyzed using different geostatistical techniques to identify areas were the occurrence of each phenomenon reached its peak and explained the findings based on the particular local evolution.

This study looked only at land cover and use changes resulting into an expansion or restructuring of urban areas, based on the CLC class indicating its final status. The general term "urban growth" was used to describe LC changes resulting into artificial areas and also LU changes of artificial areas indicating the intensification of urbanization, keeping at the same time records of the type of change (LC or LU).

Data were analyzed using ordinary kriging (Johnston et al., 2001) to produce an interpolation surface covering the national territory, similar to the study by Petrişor et al. (2010), while being aware of its limitations, discussed in the final of this paper. Nevertheless, very few areas were affected by LU changes indicating urbanization during 2000-2006, and as a result kriging maps could not be produced. These areas were represented as dots with a radius proportional to the surface changed over the kriging map depicting LC changes.

\section{Results and Discussions}

The results of looking at the most important 'hotspots' of urbanization, displayed in Figure 1 for 1990-2000 and Figure 2 for 2000-2006, locate the phenomenon around Bucharest and the seaside, tying it to the real estate boom, as suggested by Colliers International Reports (Popa and Giurcă, 2009; Strauss and Neamțu, 2006) or BNP Paribas Reports (BNP Paribas, 2008), especially since they become more visible during the second period; a third spot, evident in both periods, is located in the South-West. Similar findings have been described by Giuşcă et al. (2009) 
and Petrişor et al. (2010), who suggested a similar explanation.

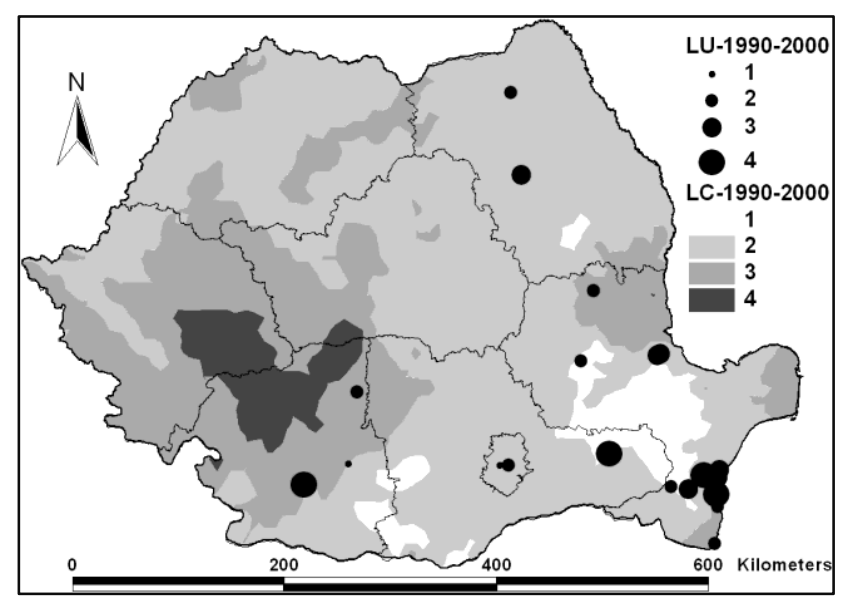

Figure 1. Displaying the spatial distribution of land cover (surfaces) and use (dots) changes in Romania during 19902000 due to the growth and transformation of cities.

The four classes correspond to gradually increasing intensities of changes displayed using darker shades and larger size of dots, both proportional to the area affected.

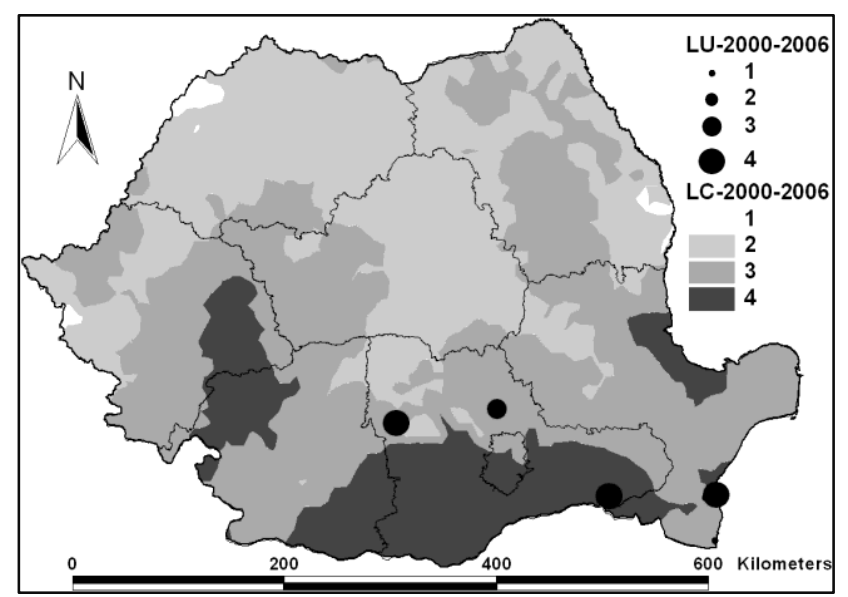

Figure 2. Displaying the spatial distribution of land cover (surfaces) and use (dots) changes in Romania during 20002006 due to the growth and transformation of cities.

The four classes correspond to gradually increasing intensities of changes displayed using darker shades and larger size of dots, both proportional to the area affected.

However, the magnitude of urbanization becomes noticeable only when looking at the share of area affected by changes from the total one in small zones, such as the region of development Bucharest-Ilfov. In larger zones and over the national territory, the phenomenon is hardly noticeable when looking at the actual area due to the small share represented by urban zones from the total area, covered mainly by agricultural and natural lands. A better way to reveal the reality is to ratio the area affected by changes to the total urban area at the end of the period (Table 1).

There are differences in the extent of urbanization between the two periods covered by CORINE data. While the phenomenon is somewhat important during 1990-2000, it becomes prominent during 2000-2006, period coinciding with the real estate boom. The statement is supported by the higher percentage of changes during the second period overall and in most regions. Nevertheless, the regions where the trend is reverted are South-East and SouthWest; the explanation seems to consist of the decline of former mining cities that lost their industrial function (Ianoş, 200o; Petrişor et al., 2010). In support of this finding, it is important to look at the differences between land cover and use changes, indicated by the top and bottom part of Table 1. The difference shows that urban growth resulted into a greater extent into land use changes than land cover changes. The explanation is that transformations occurred more within the cities than at its fringe, and is consistent with the fact that developers preferred land situated within the city limits due to the availability and proximity of utilities, determining the restructuring of intra-urban areas (Popa, 2011).

The consequences of rapid urban growth at the micro-scale have been analyzed from the urban theory perspective by Stan (2010). The author ties the rapid growth to a low quality of urban peripheries, containment of specific communities in these areas (ecological racism). Along with a poor development of the transport services tying them to the center, these social and environmental issues at are the core of causes prevent their sustainable development (Alpopi, 2007). In a theoretical context, the situation explains why Romanian peripheries do not act like an ecotone, tying the ecosystems, but separate them instead.

From a methodological perspective, the advantages of the method are also its most important limitation. While able to generalize the situation at a national level, the method lacks the power of other local approaches to pinpoint aspects relevant at the city scale, very important for the particular case of Romania, where most cities do not expand over large areas. This limitation has also been underlined by other studies (Ianoș et al., 2011; Petrișor et al., 2010). For this particular reason, results must be correlated with other studies (e.g., correlation of the hotspots in Figure 1 and Figure 2 with the studies by Giușcă et al. (2009) and Petrişor et al. (2010)), with statistical data and local information (Ianoş et al., 2011), and, most important, with field studies.

Overall, the results indicated that urban growth was uneven in Romania. Most of the cities that recorded urban growth have a particular situation: Bucharest is the capital and attracted investments; some regional centers (Iaşi) had a similar situation, but at a different scale; and other cities - particularly in the South East and Carpathians - are situated in areas attracted tourism and their growth was due to 
Table 1. Displaying the areas affected by land cover and use changes in the Romanian regions of development and overall due to the growth and transformation of cities.

\begin{tabular}{|c|c|c|c|c|c|c|c|c|}
\hline \multicolumn{9}{|c|}{ Land cover changes } \\
\hline & \multicolumn{2}{|c|}{ Count } & \multicolumn{2}{|c|}{ Area (ha) } & \multicolumn{2}{|c|}{ \% region area } & \multicolumn{2}{|c|}{$\%$ urban area } \\
\hline $\begin{array}{c}\text { Period } \rightarrow \\
\text { Region } \downarrow\end{array}$ & $1990-2000$ & 2000-2006 & $1990-2000$ & 2000-2006 & 1990-2000 & 2000-2006 & $1990-2000$ & 2000-2006 \\
\hline Buc-IF & 28 & 21 & 834 & 910 & 0.4587 & 0.5004 & 2.4075 & 2.6265 \\
\hline Center & 13 & 72 & 321 & 1110 & 0.0094 & 0.0325 & 0.2185 & 0.7542 \\
\hline NE & 54 & 119 & 1041 & 2097 & 0.0282 & 0.0568 & 0.3074 & 0.6190 \\
\hline NW & 15 & 97 & 381 & 1504 & 0.0111 & 0.0440 & 0.1881 & 0.7430 \\
\hline S & 19 & 24 & 404 & 493 & 0.0117 & 0.0143 & 0.1746 & 0.2134 \\
\hline SE & 92 & 61 & 2359 & 1343 & 0.0660 & 0.0376 & 1.1851 & 0.6747 \\
\hline SW & 75 & 44 & 2938 & 1197 & 0.1008 & 0.0411 & 1.5767 & 0.6425 \\
\hline W & 15 & 35 & 351 & 542 & 0.0109 & 0.0169 & 0.2295 & 0.3546 \\
\hline Romania & 310 & 473 & 8599 & 9196 & 0.0361 & 0.0386 & 0.5750 & 0.6149 \\
\hline \multicolumn{9}{|c|}{ Land use changes } \\
\hline & \multicolumn{2}{|c|}{ Count } & \multicolumn{2}{|c|}{ Area (ha) } & \multicolumn{2}{|c|}{$\%$ region area } & \multicolumn{2}{|c|}{$\%$ urban area } \\
\hline $\begin{array}{c}\text { Period } \rightarrow \\
\text { Region } \downarrow\end{array}$ & $1990-2000$ & 2000-2006 & $1990-2000$ & 2000-2006 & $1990-2000$ & 2000-2006 & $1990-2000$ & $2000-2006$ \\
\hline Buc-IF & 2 & & 49 & & 0.0272 & & 0.1347 & \\
\hline \multicolumn{9}{|l|}{ Center } \\
\hline NE & 3 & & 96 & & 0.0026 & & 0.0291 & \\
\hline \multicolumn{9}{|l|}{ NW } \\
\hline $\mathrm{S}$ & 1 & 4 & 64 & 137 & 0.0019 & 0.0040 & 0.0276 & 0.0590 \\
\hline SE & 18 & 3 & 672 & 88 & 0.0188 & 0.0025 & $0.335^{2}$ & 0.0440 \\
\hline SW & 4 & & 151 & & 0.0052 & & 0.0794 & \\
\hline \multicolumn{9}{|l|}{$\mathrm{W}$} \\
\hline Romania & 28 & 7 & 1032 & 225 & 0.0043 & 0.0009 & 0.0688 & $0.015^{0}$ \\
\hline
\end{tabular}

the residential areas. A similar pattern is found in areas situated in the closest rural areas around large cities. This can be a form of downshifting, taking a particular manifestation in Romania (Dumbravă, 2005).

\section{Conclusions}

The paper addressed the hypothesis according to which the post-transition urban development in Romania often took the form of sprawl and was reflected by land cover and use changes at a national scale. Nevertheless, results indicate that the extent of urban growth at this scale is masked by the small share of urban areas from the national territory; it becomes visible only in areas attractive during the real estate boom due to the price of land (large regional and national centers) or environmental conditions (sea and mountain resorts). In methodological terms, while generalizing techniques, such as kriging, can suggest the areas where growth was prominent, it can also be documented by figures when looking at the share of changes from the urban area only.

\section{Acknowledgements}

The author would like to thank anonymous reviewers for their valuable comments, which helped improving the quality of the manuscript.

\section{References}

Alpopi, C 2007, 'Prerequisites for a sustainable model of cities development', Theoretical and Empirical Researches in Urban Management, vol. 2, nr. 4, p. 1-8.

BNP, P 2008, Bucharest Property, Mid year 2008, Atisreal, Bucharest.

Botnariuc, N \& Vădineanu, A 1982, Ecologie, Editura Didactică şi Pedagogică, Bucharest.

Bullard, RD 2004, Environment and Morality. Confronting Environmental Racism in the United States, Switzerland, United Nations Research Institute for Social Development. 
Dumbravă, E 2005, Fenomenul downshifting - sau „dincolo“ de top management, HR-România, http://www.hrromania.ro/articole_afis.php?artId=1604.

European Commission, 2001, Manual of concepts on land cover and land use information systems, Office for Official Publications of the European Communities, Luxemburg.

European Environment Agency - EEA, 2006, Urban sprawl in Europe. The ignored challenge, Office for Official Publications of the Europe and Communities, Luxemburg.

Holling, CS 2004, 'From complex regions to complex worlds', Ecology and Society, vol. 9, nr. 1, http://www.ecologyandsociety.org/volg/issi/artı1/.

Ianoş, I 2000, 'Romanian towns: from extensive industrialisation to ruralisation?', The Geographical Journal of Korea, vol. 34, p. 125-136.

Ianoş, I, Petrişor, AI, Stoica, VI, Sârbu, CN, Zamfir, D \& Cercleux, AL 2011, 'The different consuming of primary eco-energies and their degradation in territorial systems', Carpathian Journal of Earth and Environmental Sciences, vol. 6, nr. 2, p. 251-26o.

Jensen, JR 2000, Remote Sensing of the Environment. An Earth Resource Perspective, Prentice Hall, Upper Saddle River, New Jersey.

Johnston, K, Ver Hoef, JM, Krivoruchko, K \& Lucas, N 2001, Using ArcGIS Geostatistical Analyst, ESRI Press, Redlands, CA.

Lacaze, JP 1990, Les méthodes de l'urbanisme, Deuxième édition corigée, Presses Universitaires de France, Paris.

Mitrea, V 2008, 'Creşterea orașelor', Arhitext, nr. 4, p. 92-95.

Petrişor A.-I., (2008a), Ecologie urbană, dezvoltare spațială durabilă şi legislaţie, Bucharest, Editura Fundaţiei România de mâine.
Petrişor, AI \& Sârbu, CN 2010, 'Dynamics of geodiversity and eco-diversity in territorial systems', Journal of Urban and Regional Analysis, vol. 2, nr. 1, p. 61-70.

Petrişor, AI 2008, 'Levels of biological diversity: a spatial approach to assessment methods', Romanian Review of Regional Studies, vol. 4, nr. 1, p. 41-62.

Petrişor, AI 2011, Systemic theory applied to ecology, geography and spatial planning. Theoretical and methodological developments, Lambert Academic Publishing, Saarbrücken.

Petrişor, AI, Ianoș, I \& Tălângă, C 2010, 'Land cover and use changes focused on the urbanization processes in Romania', Environmental Engineering and Management Journal, vol. 9, nr. 6, p. 765-771.

Popa, A \& Giurcă Vasilescu L 2009, 'The real estate investments and the financial crisis in Romania', Finance - Challenges of the Future, vol. 8, nr. 10, p. 65-70.

Popa, $\mathrm{N}$ 2011, 'Stakes in contention and mutations in the organisation of the urban and periurban space of Timișoara', Revista Română de Geografie Politică, vol. 13, nr. 2, p. 109-132.

Salas-Olmedo H \& Nogués S 2010, 'The land use and transport relationship in peripheral areas: policy integration based on case studies', General Proceedings of the 12th World Conference on Transport Research Society, Lisbon, Portugal.

Stan, AI 2009, Peisajul periferiilor urbane: revitalizarea peisageră a zonelor periferice, Editura Universitară Ion Mincu, Bucharest.

Stan, AI 2010, 'Cultură urbană - peisaj cultural urban', Urbanism. Arhitectură. Construcții, vol. 1, nr. 1, p. 19-24.

Strauss, EJ \& Neamţu, B 2006, 'Policy tools for addressing urban sprawl: Urban growth boundaries (II)', Transylvanian Review of Administrative Sciences, vol. 16, p. 136-153. 